\title{
Synthesis of glycerin carbonate-based intermediates using thiol-ene chemistry and isocyanate free polyhydroxyurethanes therefrom $\dagger$
}

\author{
Sofia Benyahya, ${ }^{a}$ Myriam Desroches, ${ }^{a}$ Rémi Auvergne, ${ }^{* a}$ Stéphane Carlotti, ${ }^{b}$ Sylvain Caillol ${ }^{a}$ \\ and Bernard Boutevin ${ }^{a}$
}

Received 24th June 2011, Accepted 5th August 2011

DOI: 10.1039/c1py00289a

A new synthesis of 4-[(prop-2-en-1-yloxy)methyl]-1,3-dioxolan-2-one (AGC) was performed by Williamson ether synthesis from 4-(hydroxymethyl)-1,3-dioxolan-2-one. Dicyclocarbonates were synthesized by UV thiol-ene coupling of allyl-cyclocarbonate with a $2,2^{\prime}$-oxydiethanethiol. This photochemical thiol-ene reaction was carried out under air, with neither solvent nor photoinitiator. The products, obtained with high yield, were characterized by ${ }^{1} \mathrm{H}$ NMR and FTIR analysis. The synthesized dicyclocarbonates were used without purification to synthesize polyhydroxyurethanes without isocyanate by step growth polyaddition with 1,10-diaminodecane. The synthesized polyhydroxyurethanes were characterized by ${ }^{1} \mathrm{H}$ NMR, FTIR, ATG and DSC analysis. These polyhydroxyurethanes exhibited glass transition temperatures from $-31{ }^{\circ} \mathrm{C}$ to $-14{ }^{\circ} \mathrm{C}$, molecular weight from $7,000 \mathrm{~g} \mathrm{~mol}^{-1}$ to $9000 \mathrm{~g} \mathrm{~mol}^{-1}$ and degradation temperature for $5 \%$ of weight loss $\left(T_{\mathrm{d}} 5 \%\right)$ between $227^{\circ} \mathrm{C}$ and $250{ }^{\circ} \mathrm{C}$.

\section{Introduction}

Polyurethanes (PUs) are one of the most dynamic groups of polymers, exhibiting versatile properties suitable for use in practically all fields of polymer applications - foams, elastomers, thermoplastics, thermorigids, adhesives, coatings, sealants, fibers and so on. Generally, PUs are obtained from the reaction of an oligomeric polyol (low molar mass polymer with terminal hydroxyl groups) and a diisocyanate (or polyisocyanate). However, the use of diisocyanate should be avoided for several reasons. Isocyanate reactants are generally very harmful for human health, particularly for people exposed during polyurethane synthesis, and could entail adverse health effects such as asthma, dermatitis, conjunctivitis and acute poisoning. ${ }^{1}$ Moreover, isocyanates are synthesized from phosgene which is a very toxic chemical that raises questions in industry. Therefore the synthesis of PUs from step growth polyaddition of dicyclocarbonates and diamines should be favored. ${ }^{2,3}$ Thus, this old reaction is currently gaining a great deal of attention as a substitution route for the synthesis of PUs. This method is particularly

\footnotetext{
${ }^{a}$ Institut Charles Gerhardt Montpellier UMR 5253 - Equipe Ingénierie et Architectures Macromoléculaires, Ecole Nationale Supérieure de Chimie de Montpellier, 8 rue de l'Ecole Normale, 34296 Montpellier Cedex 5, France. E-mail: remi.auvergne@enscm.fr; Fax: +33467147220; Tel: $+33467144305$

${ }^{b}$ Laboratoire de Chimie des Polymères Organiques UMR 5629 Université Bordeaux 1/CNRS, Ecole Nationale Supérieure dev Chimie, de Biologie \& de Physique, 16 Avenue Pey-Berland, 33607 Pessac Cedex, France. E-mail: carlotti@enscbp.fr; Tel: 0540002734

$\dagger$ Electronic supplementary information (ESI) available. See DOI: $10.1039 / \mathrm{c} 1$ py00289a
}

interesting since no hazardous isocyanates are used. Moreover dicyclocarbonate reactants could be provided from renewable resources such as glycerin. This route allows polyhydroxyurethanes (PHUs) with hydrogen bonds to be obtained, presenting higher chemical and hydrolysis resistances.

The synthesis of PHUs from step growth polyaddition of dicyclocarbonates and diamines was extensively reported in the literature, particularly by Endo. ${ }^{4}$ Indeed, several cyclocarbonates were synthesized and some polyhydroxyurethanes were thereof characterized..$^{5-8}$

Several methods are used to synthesize five-membered cyclic carbonates (Scheme 1) ${ }^{9-18}$ Most of these methods are based on epoxide or diol reactants. This is also the case of dicyclocarbonate syntheses (Scheme $2(1-5))^{6,17,19-21}$ The production of methyl esters from vegetable oil leads to glycerin as a byproduct. Thus, the use of glycerin carbonate (4-(hydroxymethyl)-1,3-dioxolan-2-one) presents a great interest for the synthesis of dicyclocarbonate. Generally, syntheses of PHUs from glycerin carbonate are based on esterification reactions from glycerin carbonate and dicarboxylic acid or derivatives (Scheme 2 (6)). In a previous study, ${ }^{22}$ a five-membered dicyclocarbonate bis[(2-oxo-1,3-dioxolan-4-yl)methyl] benzene-1,4dicarboxylate $\mathbf{D C}_{\text {ter }}$ was prepared by esterification of carboxylic acid groups of benzene-1,4-dicarboxylic acid with alcohol function of commercial 4-(hydroxymethyl)-1,3-dioxolan-2-one. This method was also reported by other authors for the synthesis of various polydicyclocarbonates, either symmetric or asymmetric..$^{823}$ Dicyclocarbonates synthesized present ester bonds on the carbon chain, thus the resulting materials are more sensitive to hydrolysis reaction. 


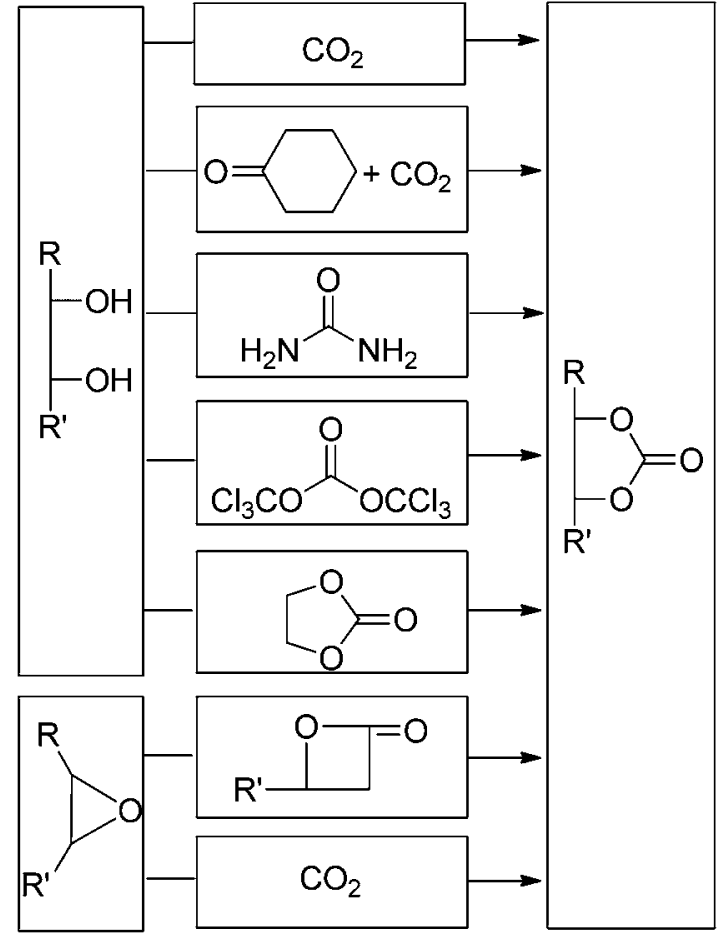

Scheme 1 Various synthesis routes to obtain cyclic carbonates molecules.

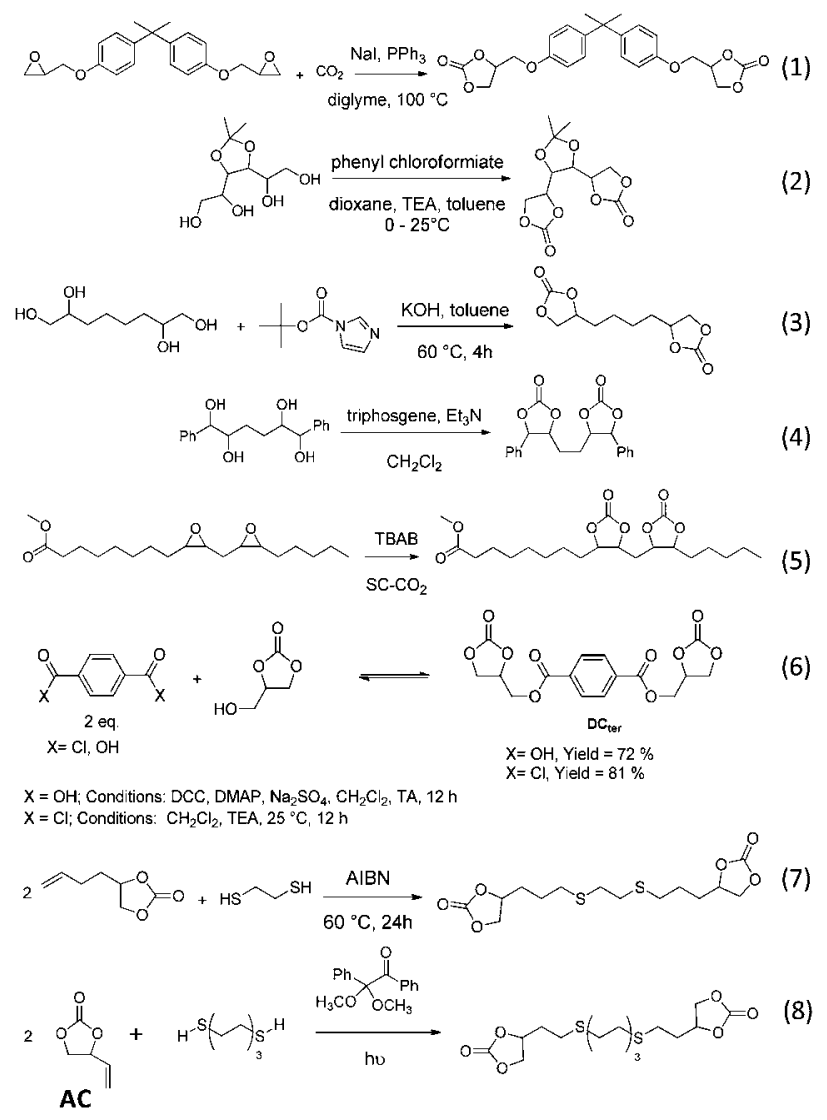

Scheme 2 Various dicyclocarbonate synthesis routes.
Furthermore, the synthesis of thioether five- and six-membered dicyclocarbonates by radical addition of ethane-1,2-dithiol with 4-(3-butenyl)-1,3-dioxolan-2-one(Scheme 2 (7)) $)^{14}$ or by reaction between 4-ethenyl-1,3-dioxolan-2-one (AC) and several thiols $(\text { Scheme } 2(8))^{24}$ has been reported. These dicyclocarbonates allow polyhydroxyurethanes to be obtained without ester bonds. However, these monomers were not synthesized from glycerol derivatives and were very expensive.

Another cyclocarbonate monomer is reported in the literature, the 4-[(prop-2-en-1-yloxy)methyl]-1,3-dioxolan-2-one (AGC). AGC was obtained by different methods (Scheme 3) without the use of glycerin carbonate derivatives.

According to the literature, AGC molecule was generally synthesized by reaction between carbon dioxide and allyl glycidyl ether by homogeneous ${ }^{25}$ or heterogeneous ${ }^{26}$ catalysis (Scheme 3 (9)). Indeed, Schmidt reported the synthesis of 4-((allyloxy)methyl)1,3-dioxolan-2-one by carbonylation of oxiran-2-ylmethyl prop-2en-1-yl carbonate in the presence of chromium (III) octaethylporphyrinato tetracarbonylcobaltate $\left[(\mathrm{OEP})-\mathrm{Cr}(\mathrm{THF})_{2}\right]\left[\mathrm{Co}(\mathrm{CO})_{4}\right]$ (Scheme 3 (9)). ${ }^{27}$ This carbonate was also synthesized from reaction between 4-methyloxetan-2-one and 2-[(prop-2-en-1-yloxy)methyl] oxirane with tetrabutylazanium bromide TBAB (Scheme $3(10))^{9}$ or by transcarbonatation between an allyl-diol and an organic carbonate (Scheme 3 (11)). ${ }^{28}$ Finally, AGC was synthesized from reaction between propane-1,2,3-triol and 4-(chlorooxy)-4-oxobut1-ene with palladium (Scheme 3 (12)). ${ }^{29}$

In the literature, thiol-ene coupling was initially reported on 4(3-butenyl)-1,3-dioxolan-2-one thermally initiated with a radical initiator and in solvent. Purifications were needed and yields varied between 50 and $60 \% .{ }^{14} \mathrm{UV}$ thiol-ene coupling with photoinitiator was also reported. ${ }^{24}$ However, the use of a photoinitiator represents a drawback since residual fragments of photoinitiator remain in the polymer and could result in accelerated ageing or yellowing of materials. In a previous study, ${ }^{30}$
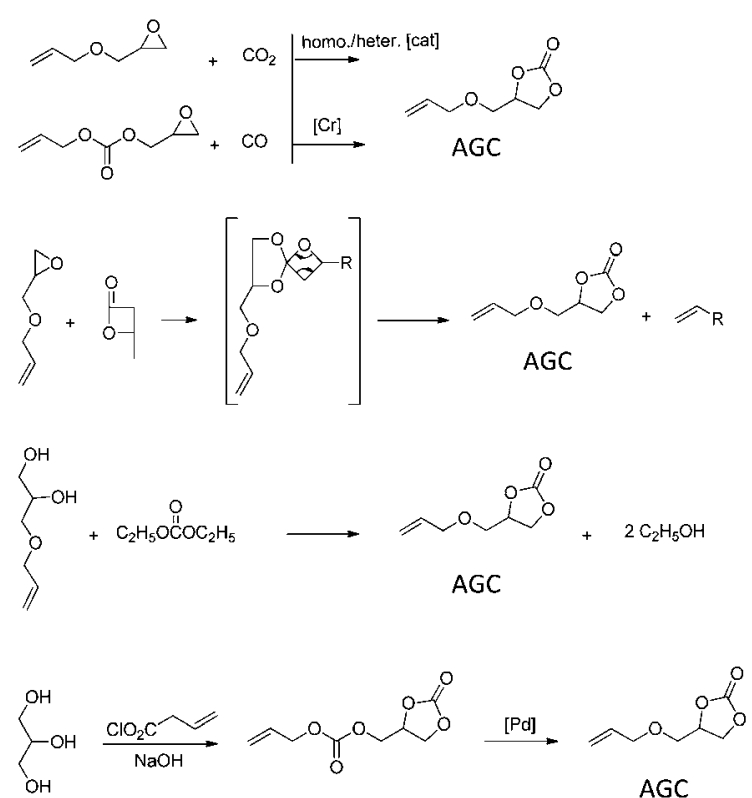

Scheme 3 Different methods for 4-[(prop-2-en-1-yloxy)methyl]-1,3dioxolan-2-one (AGC) synthesis. 
UV thiol-ene coupling on vegetable oils without any photoinitiator has been described.

Therefore, in this study, the 4-[(prop-2-en-1-yloxy)methyl]-1,3dioxolan-2-one AGC has been synthesized by a new, easy and inexpensive method, based on the use of the Williamson reaction. Synthesized AGC and commercial AC have been used to synthesize bis-AGC and bis-AC from thiol ene addition (click chemistry), and bis-AGC and bis-AC were polymerized with 1,10-diaminedecane (DA10) to obtain polyhydroxyurethane materials.

\section{Results and discussion}

Two different cyclocarbonates, 4-ethenyl-1,3-dioxolan-2-one AC and 4-[(prop-2-en-1-yloxy)methyl]-1,3-dioxolan-2-one AGC, were used for the synthesis of dicyclocarbonates bis-AC and bisAGC by thiol-ene coupling. AC cyclocarbonate is a commercial chemical, whereas the AGC cyclocarbonate was synthesized by Williamson ether reaction. As AC cyclocarbonate is a commercial product, its characterization is not reported here. The AGC cyclocarbonate synthesis is reported herein.

\section{Synthesis of dicyclocarbonates: bis-AGC and bis-AC}

Bis-AGC and bis-AC were synthesized by reaction between a dithiol and AGC or AC, respectively. This reaction was carried out by UV thiol-ene coupling without a photoinitiator (Scheme 4).

This reaction was realized without any solvent, with a thiol/ double bonds ratio of $1 / 1$ and an irradiation between 250 and 450 $\mathrm{nm}$, at $10 \mathrm{~W} \mathrm{~cm} \mathrm{~cm}^{-2}$. Firstly, dicyclocarbonate bis-AC was synthesized in one step by UV thiol-ene coupling of $2,2^{\prime}$-oxydiethanethiol on commercial cyclocarbonate AC in 2 hours. The ${ }^{1} \mathrm{H}$ NMR spectrum of the product allows clear identification of the expected product (Fig. 1).

Addition of thiol was confirmed by the disappearance of signals corresponding to the vinylic protons at $5.43 \mathrm{ppm}(\mathrm{CH}=$ $\left.\mathrm{CH}_{2}\right)$ and $5.88 \mathrm{ppm}\left(\mathrm{CH}=\mathrm{CH}_{2}\right)$, and by the appearance of signals corresponding to the thioether protons between $2.65 \mathrm{ppm}$ and $2.78 \mathrm{ppm}\left(\mathrm{CH}_{2}-\mathrm{S}\right.$, signal d, $\left.\mathrm{d}^{\prime}\right)$ and between $1.94 \mathrm{ppm}$ and 2.08 ppm $\left(\mathrm{CH}_{2}-\mathrm{CH}_{2}-\mathrm{S}\right.$, signal c, c' $)$ (Fig. 1). These signals corresponding to protons in $\alpha$ and $\beta$ positions of sulfur appeared as a multiplet dedoubled due to the vicinity of the asymmetric carbon b. The product of thiol addition on the more substituted carbon is not observed in this spectrum, which confirms the selectivity of thiol-ene coupling.

The UV thiol-ene coupling was then successfully used for the synthesis of dicyclocarbonate AGC and was carried out in 5

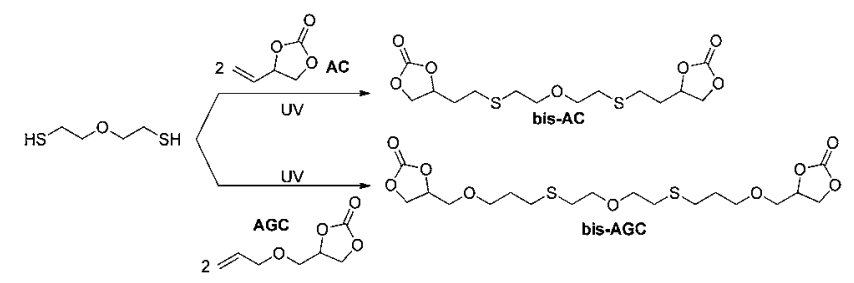

Scheme 4 Synthesis of dicyclocarbonate by thiol-ene coupling (ratio thiol/double bond of $1 / 1$, irradiated at $10 \mathrm{~W} \mathrm{~cm}^{-2}$ ). hours. This lower reactivity of this reaction is in agreement with allylic ether reactivity. As observed previously, ${ }^{1} \mathrm{H}$ NMR analysis confirmed thiol addition (Fig. 2). Indeed, the disappearance of signals corresponding to the protons of double bonds at $5.26 \mathrm{ppm}\left(\mathrm{CH}=\mathrm{CH}_{2}\right)$ and at $5.85 \mathrm{ppm}\left(\mathrm{CH}=\mathrm{CH}_{2}\right)$ and the appearance of signals corresponding to the protons of thioether in the $\alpha$ position of sulfur at $3.58 \mathrm{ppm}\left(\mathrm{CH}_{2}-\mathrm{S}\right.$, signal $\mathrm{f}$; Fig. 2) and in the $\beta$ position at $1.81 \mathrm{ppm}\left(\mathrm{CH}_{2}-\mathrm{CH}_{2} \mathrm{~S}\right.$, signal e; Fig. 2) were observed.

In this case, thiol-ene coupling for the synthesis of dicyclocarbonates fits perfectly with the Sharpless principles of "click chemistry" ${ }^{31}$ stoichiometry of reactant $1 / 1$, no solvent, no catalyst, high yield and no by-product.

\section{Polyhydroxyurethanes synthesis}

Then, step growth polyaddition of synthesized building blocks bis-AC and bis-AGC with commercial decane-1,10-diamine DA10 was carried out and yielded respectively PHU-bis-AC and PHUbis-AGC polyhydroxyurethanes (Scheme 5). Scheme 5 presents idealized structures (isomer primary-secondary alcohol); most isomers such as primary-primary alcohol, primary-secondary alcohol and secondary-secondary alcohol were obtained.

Both synthesized PHUs were characterized by ${ }^{1} \mathrm{H}$ and ${ }^{13} \mathrm{C}$ NMR spectrometry and by FTIR analysis. The ${ }^{1} \mathrm{H}$ NMR spectrum of synthesized PHU-bis-AGC is reported in Fig. 3.

This spectrum confirms the formation of the carbamate group with the signal of the proton on nitrogen at $8 \mathrm{ppm} .{ }^{32}$ The shifts of characteristic signals of carbonate function (aa', b, cc' in Fig. 2) in $a, b, c$ and $x, y, z$ (Fig. 3) are observed. These signals represent the different isomers of cyclocarbonate ring opening. Indeed, ring opening of the cyclocarbonate function by the primary amine function is not regioselective and leads to three PHU isomers, with primary and secondary alcohols..$^{4-8,33}$ The percent of primary and secondary alcohols was determined thanks to $\mathrm{y}$ and $\mathrm{b}$ proton integration according to eqn (1):

$$
R_{\mathrm{OHp}}=\frac{I_{y}}{I_{\mathrm{y}}+I_{\mathrm{b}}} \times 100
$$

where $R_{\mathrm{OHp}}, I_{\mathrm{y}}$ and $I_{\mathrm{b}}$ stand for primary alcohol percent, $\mathrm{y}$ proton integration and $\mathrm{b}$ proton integration, respectively.

The ratio of primary and secondary alcohols was 25/75, which is in agreement with Endo studies. ${ }^{34}$

The FTIR spectrum (Fig. 4) confirms formation of PHU-bisAGC polyhydroxyurethane with the three characteristic bands of the carbamate function: $\mathrm{N}-\mathrm{H}$ bond stretching vibration, hydrogen bonded $\mathrm{C}=\mathrm{O}$ stretching and $\mathrm{N}-\mathrm{H}$ bond deformation are respectively observed at $3078 \mathrm{~cm}^{-1}, 1686 \mathrm{~cm}^{-1}$ and $1530 \mathrm{~cm}^{-1}$.

The large absorption band of the hydroxyl group $\mathrm{OH}$ at 3326 $\mathrm{cm}^{-1}$ also appeared.

On the PHU-bis-AGC FTIR spectrum, the absence of the absorption band of $\mathrm{C}=\mathrm{O}$ carbonyl of the carbonate group at $1785 \mathrm{~cm}^{-1}$ reveals a total conversion of initial bis-AGC.

Table 1 summarizes the main characteristics of both synthesized PHUs, Mn (SEC), $T_{\mathrm{g}}$ (DSC) and $T_{\mathrm{d}} 5 \%$ (TGA). The corresponding figures are given in the ESI†.

As expected, the carbon chain length of dicyclocarbonate influences the $T_{\mathrm{g}}$ value of polymer obtained. Thus, the AGC monomer presents two methyl groups and one ether bond in the 


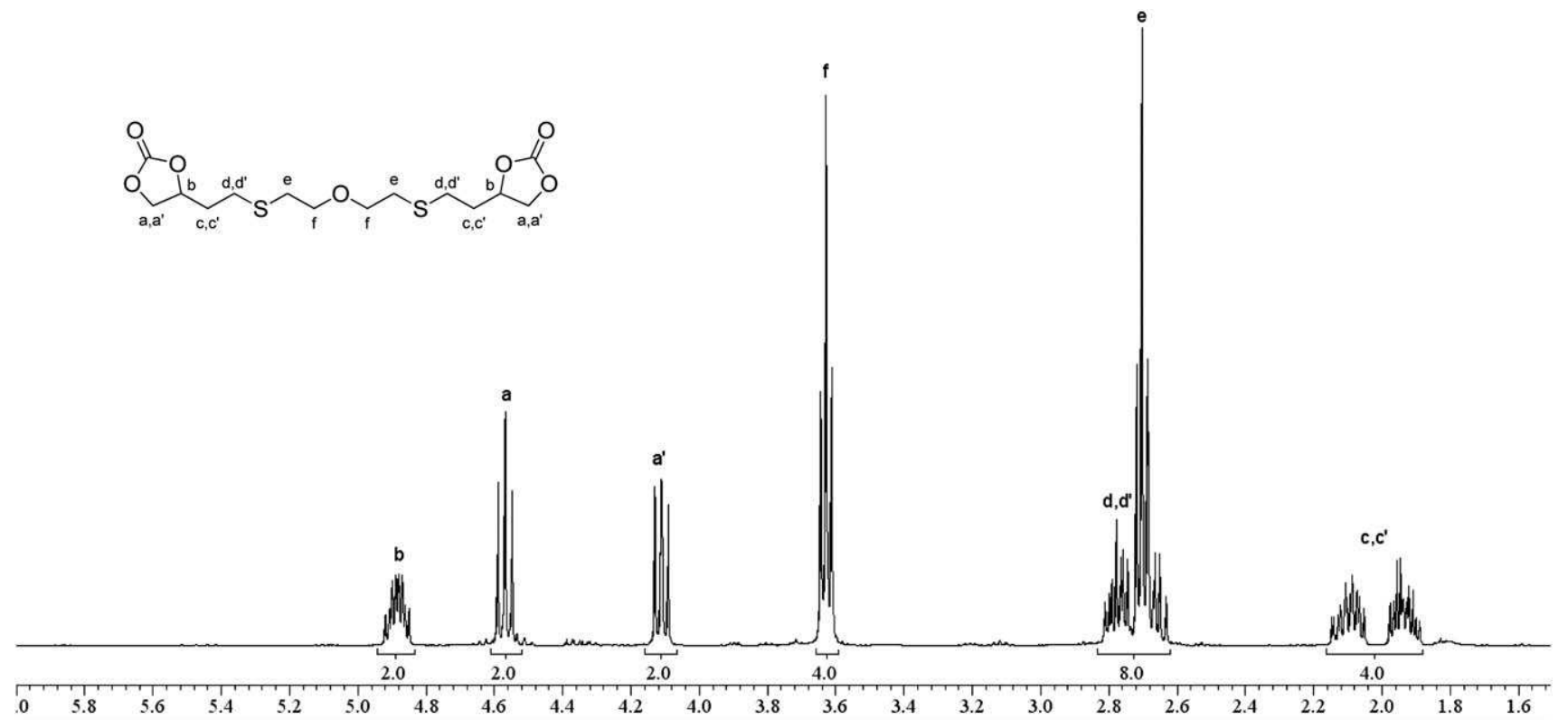

Fig. $1{ }^{1} \mathrm{H}$ NMR spectrum of commercial cyclocarbonate (AC) after thiol-ene coupling (ratio thiol/double bond of $1 / 1$, irradiated 2 hours at $10 \mathrm{~W} \mathrm{~cm}^{-2}$ ).

chain, leading to a more flexible chain than the $\mathrm{AC}$ monomer. This assumption was confirmed by $T_{\mathrm{g}}$ values $-31{ }^{\circ} \mathrm{C}$ and $-14{ }^{\circ} \mathrm{C}$ for PHU-bis-AGC and PHU-bis-AC, respectively (see the ESI, Fig. S1†).

The molecular weight values obtained were similar, 7000 and $9000 \mathrm{~g} \mathrm{~mol}^{-1}$, with polydispersity indices (PI) of 1.5 and 3.2 for

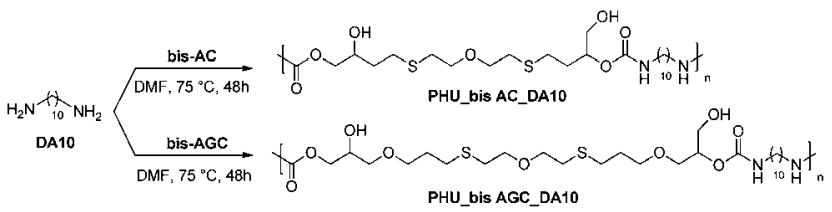

Scheme 5 Step growth polyaddition of DA10 and AC or AGC.

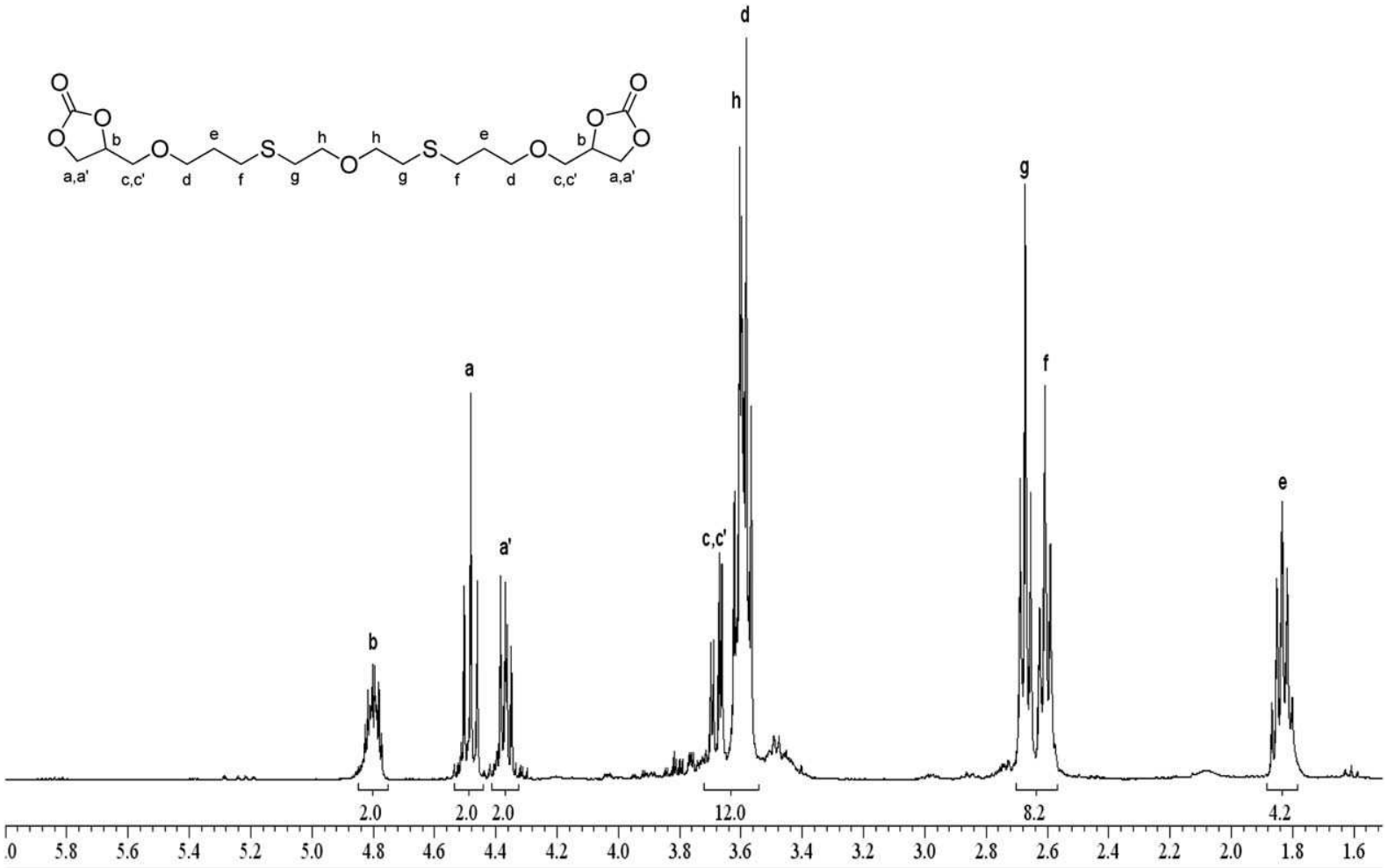

Fig. $2{ }^{1} \mathrm{H}$ NMR spectrum of synthesized cyclocarbonate (AGC) after thiol-ene coupling (ratio thiol/double bond of 1/1, irradiated 5 hours at $10 \mathrm{~W}$ $\mathrm{cm}^{-2}$ ). 


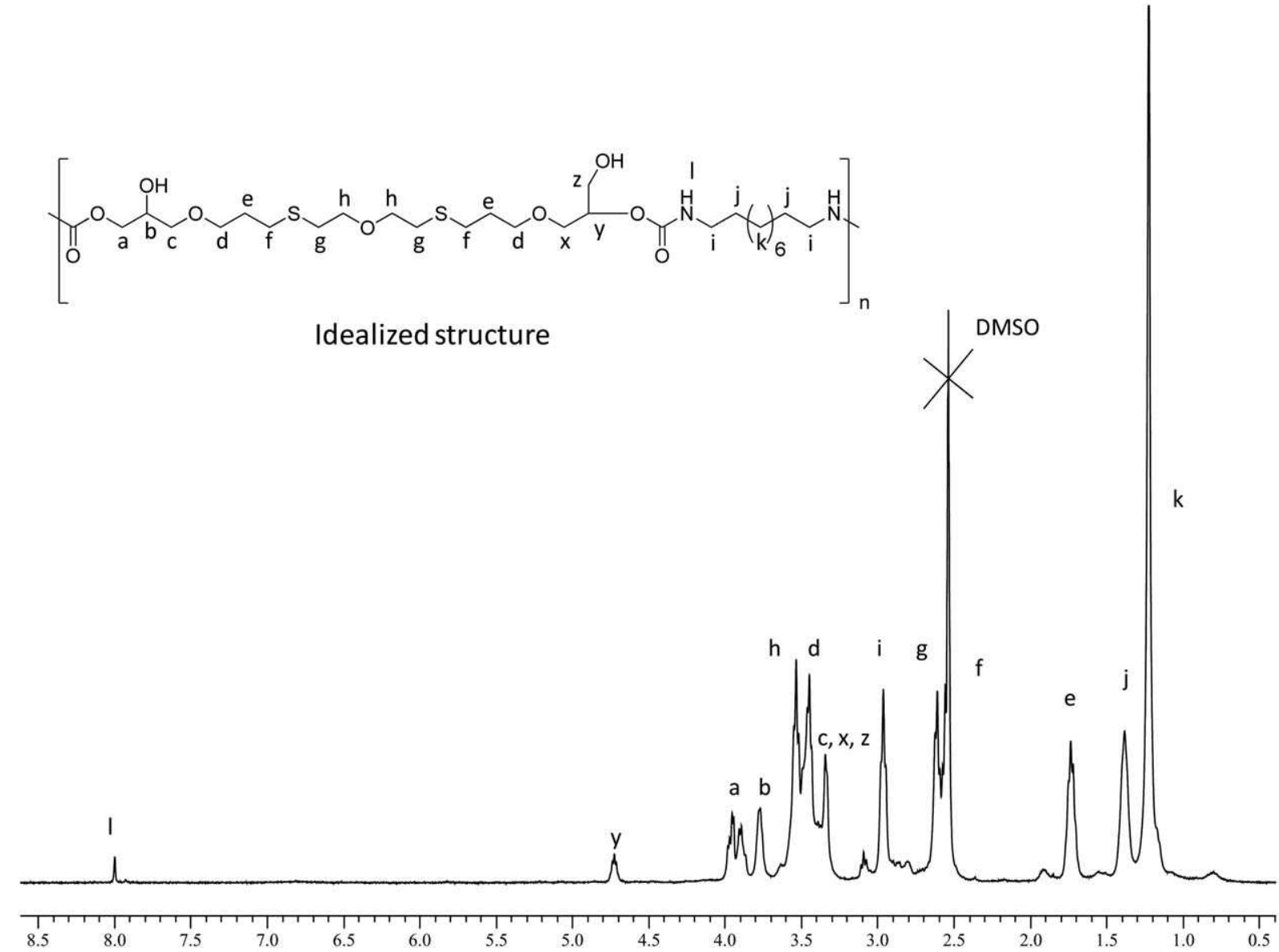

Fig. 3 1H RMN spectrum (400 MHz, DMSO-d6) of PHU-bis-AGC.

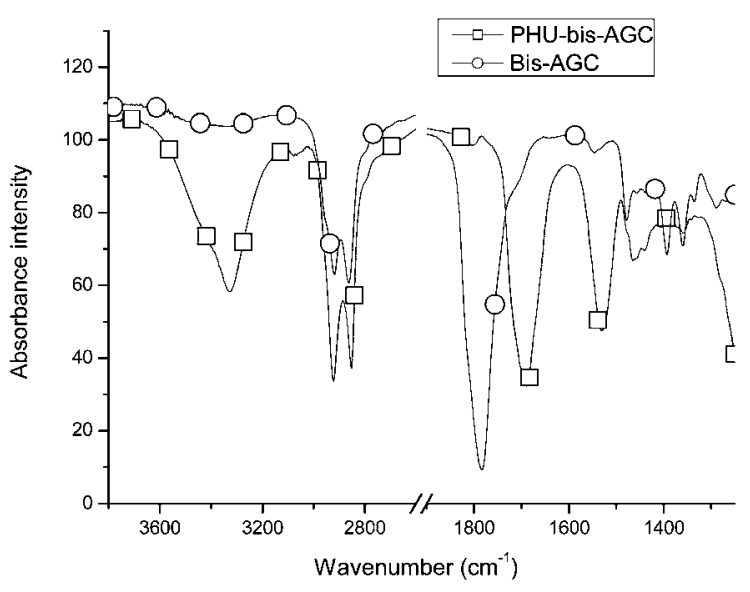

Fig. 4 Infrared spectra of bis-AGC and PHU-bis-AGC.

Table 1 Results of glass transition temperatures, degradation temperatures and molecular weights of synthesized PHUs

\begin{tabular}{lllll}
\hline PHU & $T_{\mathrm{g}} /{ }^{\circ} \mathrm{C}$ & $T_{\mathrm{d}} 5 \% /{ }^{\circ} \mathrm{C}$ & $M_{\mathrm{n}}{ }^{a} / \mathrm{g} \mathrm{mol}^{-1}$ & PI \\
\hline PHU-bis-AC & -14 & 227 & 7000 & 1.5 \\
PHU-bis-AGC & -31 & 249 & 9000 & 3.2
\end{tabular}

${ }^{a}$ SEC DMF, calibrated using PMMA standards.
PHU-bis-AC and PHU-bis-AGC, respectively. These values are low but still comparable to those reported in the literature. The SEC chromatogram is presented in the ESI, Fig. S $2 \uparrow$. Indeed, Endo et al. reported the step growth polyaddition of 4,4'-[ethane1,2-diylbis(sulfanediylbutane-4,1-diyl)]bis(1,3-dioxolan-2-one) in DMAc at $50{ }^{\circ} \mathrm{C}$ in $48 \mathrm{~h}$. This reaction led to a PHU with a yield of $67 \%$ and a molecular weight of $7500 \mathrm{~g} \mathrm{~mol}^{-1}$. After 14 days of reaction under the same conditions, a conversion of $95 \%$ is reached with a molecular weight of $15000 \mathrm{~g} \mathrm{~mol}^{-1}$ (Scheme 6). ${ }^{14}$

Finally, concerning thermal degradation measured by ATG, synthesized PHU-bis-AGC and PHU-bis-AC exhibit a degradation temperature $\left(T_{\mathrm{d}} 5 \%\right)$ of $249^{\circ} \mathrm{C}$ and $227^{\circ} \mathrm{C}$, for $5 \%$ of weight loss, respectively. These values confirm the stability of these

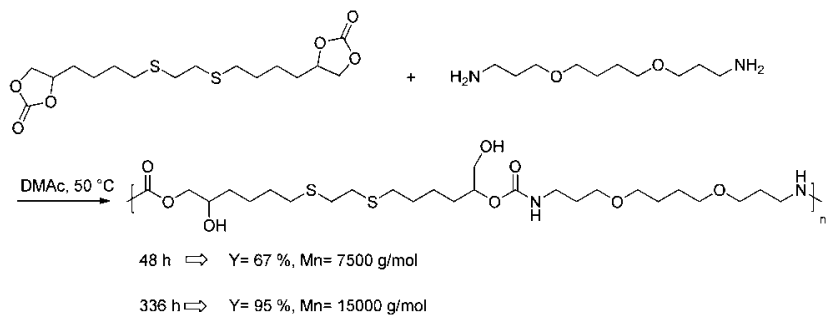

Scheme 6 Step growth polyaddition of 1,2-bis[4-(1,3-dioxolan-2-one-4yl)-butylthio)ethane with $3,3^{\prime}$-[butane-1,4-diylbis(oxy)]dipropan-1amine. ${ }^{11}$ 
polymers above $200{ }^{\circ} \mathrm{C}$, as other PUs. The thermal degradation of PHU polymers proceeds in three steps: the first step, between 250 and $350{ }^{\circ} \mathrm{C}$ (for PHU-bis-AC) and between 250 and $380{ }^{\circ} \mathrm{C}$ (for PHU-bis-AGC) for a weight loss corresponding to $75 \%$; a second degradation step until $480{ }^{\circ} \mathrm{C}$ with a weight loss of $10 \%$; and the last step until $580{ }^{\circ} \mathrm{C}$ for total degradation (see the ESI, Fig. S3†).

Concerning PHU-bis-AC, thermal degradation under air or nitrogen conditions for $5 \%$ of degradation occurred at $227{ }^{\circ} \mathrm{C}$ and $225{ }^{\circ} \mathrm{C}$, respectively. We did not observe any difference during thermal degradation under air or nitrogen conditions until $350{ }^{\circ} \mathrm{C}$. Between $350{ }^{\circ} \mathrm{C}$ and $450{ }^{\circ} \mathrm{C}$, a difference of $10 \%$ was observed, oxidation phenomena under air explain this difference. After $450{ }^{\circ} \mathrm{C}$, the polymer reaches total degradation at $580{ }^{\circ} \mathrm{C}$ (see the ESI, Fig. S4†).

\section{Experiment section}

\section{Materials}

Sodium hydride (95\%), 1,10-diaminodecane (DA10) (95\%), 3-bromo-1-propene (99\%), sodium iodide (99.99\%), 2,2'-oxydiethanethiol, 4-ethenyl-1,3-dioxolan-2-one $(99 \%) \quad$ were purchased from Sigma Aldrich and used as received. 4-(Hydroxymethyl)-1,3-dioxolan-2-one (JEFFSOL $\AA)$ was supplied by Huntsman (Saint-Mihiel, France). Sodium chloride, magnesium sulfate, tertrahydrofuran (THF) and $N, N$-dimethylmethanamide (DMF) were purchased from SDS Carlo Erba (Val de Reuil, France). Before use, THF and DMF were dried according to current methods, then distilled and stored under argon atmosphere. Deuterated solvents $\left(\mathrm{CDCl}_{3}\right.$ and DMSO) were purchased from Eurisotop (Saint-Aubin, France).

\section{Analytical techniques}

All nuclear magnetic resonance $\left({ }^{1} \mathrm{H},{ }^{13} \mathrm{C} \mathrm{NMR}\right)$ measurements were recorded on a Bruker AC-400 $\mathrm{MHz}$ spectrometer at room temperature in deuterated chloroform $\left(\mathrm{CDCl}_{3}\right)$ or dimethylsulfoxide (DMSO). The chemical shifts were reported in parts per million relative to tetramethylsilane.

IR spectra were recorded with a Nicolet 210 FT-IR spectrometer. Size exclusion chromatography (SEC) was performed on a Varian ProStar Model 210 equipped with an RI refractive index detector. Two PLgel $5 \mu \mathrm{m}$ MIXED-C $600 \mathrm{~mm}$ were used at $70{ }^{\circ} \mathrm{C}$ with a $0.8 \mathrm{~mL} \cdot \mathrm{min}^{-1}$ flow rate of $\mathrm{DMF}$, calibrated using PMMA standards. Differential scanning calorimetry (DSC) analyses were performed under inert atmosphere with a calorimeter DSC1 from Mettler Toledo. The polymer was weighted in an aluminium pan and consecutively placed in the measurement heating cell. An empty pan was used as reference. All the samples were heated under inert atmosphere from -120 to $100{ }^{\circ} \mathrm{C}$ at a heating rate of $20^{\circ} \mathrm{C} \mathrm{min}^{-1}$.

Three runs were recorded and the glass transition temperature $\left(T_{\mathrm{g}}\right)$ values were measured during the second run and confirmed by a third run. $T_{\mathrm{g}} \mathrm{s}$ were calculated at the inflexion point of the heat capacity jump.

Thermogravimetric analyses (TGA) were performed using a TGA Q50 W/MFC apparatus of TA Instruments under air flow $(25 \mathrm{ml} \mathrm{min}-1)$ from room temperature to $580{ }^{\circ} \mathrm{C}$ at a heating rate of $20{ }^{\circ} \mathrm{C} \mathrm{min}{ }^{-1}$. The analysis consisted of registering the weight loss of the sample as a function of temperature.

\section{Synthesis}

Synthesis of 4-[(prop-2-en-1-yloxy)methyl]-1,3-dioxolan-2-one (AGC). Sodium hydride $\mathrm{NaH}$ (60\% in oil, $2.43 \mathrm{~g}, 102 \mathrm{mmol})$ was added to a solution of 4-(hydroxymethyl)-1,3-dioxolan-2-one $(10 \mathrm{~g}, 85 \mathrm{mmol})$ in THF $(90 \mathrm{ml})$ at $0{ }^{\circ} \mathrm{C}$ under Ar. The reaction mixture was stirred for $10 \mathrm{~min}$ at $0{ }^{\circ} \mathrm{C}$ followed by an addition of 3-bromoprop-1-ene (15.37 g, $127 \mathrm{mmol})$ and $\mathrm{NaI}(1.26 \mathrm{~g}$, $8.47 \mathrm{mmol})$. The resulting mixture was stirred for $24 \mathrm{~h}$ at $23^{\circ} \mathrm{C}$ before being filtered and washed with saturated aqueous $\mathrm{NaCl}$, dried over $\mathrm{MgSO}_{4}$, and concentrated under reduced pressure. The product was obtained as yellow oil (10.98 $\mathrm{g}, 82 \%)$ and characterized by ${ }^{1} \mathrm{H}$ and ${ }^{13} \mathrm{C}$ NMR spectrometry.

$\mathrm{RMN}{ }^{1} \mathrm{H} / \mathrm{CDCl}_{3} \mathrm{~d}_{6}: \delta(\mathrm{ppm})=5.86-5.75\left(1 \mathrm{H}, \mathrm{m}, \mathrm{CH}_{2}=\right.$ $\mathrm{CH}-)$, 5.24-5.14 (2H, dd, $\left.\mathrm{CH}_{2}=\mathrm{CH}-\right), 4.83-4.77\left(1 \mathrm{H}, \mathrm{m}, \mathrm{CH}_{2}-\right.$ $\mathrm{CH}-\mathrm{O}-)$, 4.49-4.45 (2H, m, O-CH-CH$), 4.37-4.32(2 \mathrm{H}, \mathrm{d},=$ $\left.\mathrm{CH}-\mathrm{CH}_{2}-\mathrm{O}\right), 3.67-3.54\left(2 \mathrm{H}, \mathrm{m}, \mathrm{CH}_{2}-\mathrm{O}-\mathrm{CH}_{2}\right)$.

$\mathrm{RMN}{ }^{13} \mathrm{C} \mathrm{CDCl}_{3} \mathrm{~d}_{6}: \delta(\mathrm{ppm})=155.4(\mathrm{O}-\mathrm{CO}-\mathrm{O}), 115.45$ $\left(\mathrm{CH}_{2}=\mathrm{CH}-\right), 132.8\left(\mathrm{CH}_{2}=\mathrm{CH}-\right), 75.77\left(\mathrm{CH}_{2}-\mathrm{O}-\mathrm{CH}_{2}\right), 72(\mathrm{O}-$ $\left.\mathrm{CH}-\mathrm{CH}_{2}\right), 71.8\left(=\mathrm{CH}-\mathrm{CH}_{2}-\mathrm{O}\right), 61.7\left(\mathrm{O}-\mathrm{CH}-\mathrm{CH}_{2}\right)$.

Bis AG and bis AGC syntheses by thiol-ene coupling. Photochemical thiol-ene reaction was performed in quartz reactors of $20 \mathrm{~mL}$ equipped with an Ultracure 100SS plus/Novacure lamp (unfiltered radiation between 250 and $450 \mathrm{~nm}$ ) and a magnetic stirrer under air. After cyclocarbonate $(2.50 \mathrm{~g})$ and 2,2'-oxydiethanethiol (1.52 $\mathrm{g}$ for 4-ethenyl-1,3-dioxolan-2-one $\mathrm{AC}$ and $1.11 \mathrm{~g}$ for the synthesized AGC) introduction, the homogeneous reaction mixture was irradiated for several hours at $10 \mathrm{~W} \mathrm{~cm}^{-2}$. During reaction, the photochemical beam was stopped every hour to remove aliquots. The conversion of double bonds was monitored by ${ }^{1} \mathrm{H}$ NMR spectrometry (vinyl proton signals at 5.4 and $5.9 \mathrm{ppm}$ ). No purification was carried out. The product was obtained as a viscous liquid.

RMN ${ }^{1} \mathrm{H}$ of $\mathrm{Bis} \mathrm{AG} / \mathrm{CDCl}_{3} \mathrm{~d}_{6}: \delta(\mathrm{ppm})=4.90(1 \mathrm{H}, \mathrm{m}), 4.57$ $(1 \mathrm{H}, \mathrm{t}), 4.12(1 \mathrm{H}, \mathrm{t}), 3.62(2 \mathrm{H}, \mathrm{t}), 2.77(2 \mathrm{H}, \mathrm{m}), 2.70(2 \mathrm{H}, \mathrm{t}), 1.95-$ $2.10(2 \mathrm{H}, \mathrm{m})$.

$\mathrm{RMN}{ }^{13} \mathrm{C}$ of Bis $\mathrm{AG} / \mathrm{CDCl}_{3} \mathrm{~d}_{6}: \delta(\mathrm{ppm})=155.0(\mathrm{O}-\mathrm{CO}-\mathrm{O})$, $75.8\left(\mathrm{O}-\mathrm{CH}-\mathrm{CH}_{2}\right), 70.9\left(\mathrm{O}-\mathrm{CH}_{2}-\mathrm{CH}_{2}-\mathrm{S}\right), 69.4\left(\mathrm{CO}-\mathrm{O}-\mathrm{CH}_{2}-\right.$ $\mathrm{CH}), 34.1\left(\mathrm{O}-\mathrm{CH}_{2}-\mathrm{CH}_{2}-\mathrm{S}\right), 32.0\left(\mathrm{CH}-\mathrm{CH}_{2}-\mathrm{CH}_{2}-\mathrm{S}\right), 27.8(\mathrm{CH}-$ $\left.\mathrm{CH}_{2}-\mathrm{CH}_{2}-\mathrm{S}\right)$.

RMN ${ }^{1} \mathrm{H}$ of Bis $\mathrm{AGC} \mathrm{CDCl}_{3} \mathrm{~d}_{6}: \delta(\mathrm{ppm})=4.80(1 \mathrm{H}, \mathrm{m}), 4.50$ $(1 \mathrm{H}, \mathrm{t}), 4.38(1 \mathrm{H}, \mathrm{t}) 3.70(2 \mathrm{H}, \mathrm{m}), 3.60(2 \mathrm{H}, \mathrm{t}), 3.58(2 \mathrm{H}, \mathrm{t}), 2.68$ $(2 \mathrm{H}, \mathrm{t}), 2.60(2 \mathrm{H}, \mathrm{t}), 1.82(2 \mathrm{H}, \mathrm{m})$.

$\mathrm{RMN}{ }^{13} \mathrm{C}$ of $\mathrm{Bis} \mathrm{AGC} / \mathrm{CDCl}_{3} \mathrm{~d}_{6}: \delta(\mathrm{ppm})=154.6(\mathrm{O}-\mathrm{CO}-\mathrm{O})$, $74.6\left(\mathrm{O}-\mathrm{CH}-\mathrm{CH}_{2}\right), 70.0\left(\mathrm{O}-\mathrm{CH}_{2}-\mathrm{CH}_{2}-\mathrm{S}\right), 69.7(\mathrm{CO}-\mathrm{O}-\mathrm{CH}-$ $\left.\mathrm{CH}_{2}-\mathrm{O}\right), 69.4\left(\mathrm{CO}-\mathrm{O}-\mathrm{CH}_{2}-\mathrm{CH}\right), 65.5\left(\mathrm{O}-\mathrm{CH}_{2}-\mathrm{CH}_{2}-\mathrm{CH}_{2}-\mathrm{S}\right)$, $31.1\left(\mathrm{O}-\mathrm{CH}_{2}-\mathrm{CH}_{2}-\mathrm{S}\right), 29.0\left(\mathrm{O}-\mathrm{CH}_{2}-\mathrm{CH}_{2}-\mathrm{CH}_{2}-\mathrm{S}\right), 28.5(\mathrm{O}-$ $\left.\mathrm{CH}_{2}-\mathrm{CH}_{2}-\mathrm{CH}_{2}-\mathrm{S}\right)$.

\section{Polyhydroxyurethane (PHU-bis-AC and PHU-bis-AGC) syntheses}

Step growth polyaddition of dicyclocarbonates bis-AC and bisAGC was realized with DA10 under stirring in distilled DMF and under argon atmosphere at $75^{\circ} \mathrm{C}$ during $48 \mathrm{~h}$. At the end of 
reaction, DMF is evaporated and PHU-bis-AC and PHU-bisAGC polymers were precipitated in methanol. After drying, PHUs were quantitatively obtained.

Both synthesized PHUs were characterized by ${ }^{1} \mathrm{H}$ NMR spectrometry and by FTIR analysis. Only ${ }^{1} \mathrm{H}$ NMR and FTIR spectra of bis-AGC dicyclocarbonate and PHU-bis-AGC corresponding polyhydroxyurethane are reported.

\section{Conclusion}

A new one-step synthesis of 4-[(prop-2-en-1-yloxy)methyl]-1,3dioxolan-2-one AGC, from 4-(hydroxymethyl)-1,3-dioxolan-2one (glycerol derivatives), has been reported. This route is particularly interesting since it is an inexpensive, one-step synthesis from biobased glycerin carbonate. Then precursors of PHU have been synthesized by thiol-ene coupling of dithiol with AGC and AC. This "click-chemistry" reaction is particularly advantageous since it requires neither solvent nor photoinitiator and is quantitative in stoichiometric conditions. Finally, polyhydroxyurethanes have been synthesized by step growth polyaddition reaction of bis-AC and bis-AGC with 1,10-diaminedecane. This reaction, carried out without isocyanates, is a less hazardous synthesis. The synthesized polyhydroxyurethanes contain neither hydrolysis sensitive ester bonds nor UV sensitive aromatic groups and exhibit low $T_{\mathrm{g}}$, therefore they could profitably be used in exterior coatings.

\section{Acknowledgements}

This work was supported by ANR project MatetPro, Resipoly Chrysor and SEG Dielectriques companies, the authors thank Pr. Alain Fruchier for fruitful discussion.

\section{References}

1 M. H. Karol and J. A. Kramarik, Toxicol. Lett., 1996, 89, 139-146. 2 W. Ried and W. Merkel, Angew. Chem., Int. Ed. Engl., 1969, 8, 379380.

3 H. Tomita, F. Sanda and T. Endo, J. Polym. Sci., Part A: Polym. Chem., 2001, 39, 3678-3685.

4 A. Steblyanko, W. Choi, F. Sanda and T. Endo, J. Polym. Sci., Part A: Polym. Chem., 2000, 38, 2375-2380.

5 N. Kihara and T. Endo, J. Polym. Sci., Part A: Polym. Chem., 1993, 31, 2765-2773.
6 M.-R. Kim, H.-S. Kim, C.-S. Ha, D.-W. Park and J.-K. Lee, J. Appl. Polym. Sci., 2001, 81, 2735-2743.

7 L. Ubaghs, N. Fricke, H. Keul and H. Höcker, Macromol. Rapid Commun., 2004, 25, 517-521.

8 Q. Li, W. Zhang, N. Zhao, W. Wei and Y. Sun, Catal. Today, 2006, 115, 111-116.

9 CN101376632A, 2009.

10 T. Nishikubo, T. Iizawa, M. Iida and N. Isobe, Tetrahedron Lett., 1986, 27, 3741-3744.

11 M. Aresta, A. Dibenedetto, C. Dileo, I. Tommasi and E. Amodio, J. Supercrit. Fluids, 2003, 25, 177-182.

12 B. M. Bhanage, S.-i. Fujita, Y. Ikushima and M. Arai, Green Chem., 2003, 5, 429-432.

13 H. Tomita, F. Sanda and T. Endo, J. Polym. Sci., Part A: Polym. Chem., 2001, 39, 860-867.

14 H. Tomita, F. Sanda and T. Endo, J. Polym. Sci., Part A: Polym. Chem., 2001, 39, 4091-4100.

15 H. Tomita, F. Sanda and T. Endo, J. Polym. Sci., Part A: Polym. Chem., 2001, 39, 162-168.

16 H. Komura, T. Yoshino and Y. Ishido, Bull. Chem. Soc. Jpn., 1973, 46, 550-553.

17 K. Weissermel, Industrial Organic Chemistry, Wiley-VCH, 3rd edn, 1997.

18 M. Aresta, A. Dibenedetto, C. Dileo, I. Tommasi and E. Amodio, J. Supercrit. Fluids, 2003, 25, 177-182.

19 G. Proempers, H. Keul and H. Hoecker, Des. Monomers Polym., 2005, 8, 547-569.

20 S. P. Rannard and N. J. Davis, Org. Lett., 1999, 1, 933-936.

21 K. T. Sprott and E. J. Corey, Org. Lett., 2003, 5, 2465-2467.

22 S. Benyahya, B. Boutevin, S. Caillol, V. Lapinte, J.-P. Habas, 2011. submitted.

23 DE3937116A1, 1991.

24 C. N. Tang, H. B. Nulwala, K. Damodaran, P. Kaur and D. R. Luebke, J. Polym. Sci., Part A: Polym. Chem., 2011, 49, 2024-2032.

25 C. Qi, H. Jiang, Z. Wang, B. Zou and S. Yang, Synlett, 2007, 255-258.

26 Y. Xiong, H. Wang, R. Wang, Y. Yan, B. Zheng and Y. Wang, Chem. Commun., 2010, 46, 3399-3401.

27 J. A. R. Schmidt, E. B. Lobkovsky and G. W. Coates, J. Am. Chem. Soc., 2005, 127, 11426-11435.

28 Z. Zhang, L. J. Lyons, R. West, K. Amine and R. West, Silicon Chem., 2007, 3, 259-266.

29 F. Guibe and M. L. Y. Saint, Tetrahedron Lett., 1981, 22, 3591-3594.

30 M. Desroches, S. Caillol, V. Lapinte, R. Auvergne and B. Boutevin, Macromolecules (Washington, DC, U.S.), 2011, 44, 2489-2500.

31 H. C. Kolb, M. G. Finn and K. B. Sharpless, Angew. Chem., Int. Ed., 2001, 40, 2004-2021.

32 B. Boutevin, J. P. Hugon and Y. Pietrasanta, Eur. Polym. J., 1981, 17, 723-727.

33 H. Tomita, F. Sanda and T. Endo, J. Polym. Sci., Part A: Polym. Chem., 2001, 39, 851-859.

34 B. Ochiai, S.-I. Sato and T. Endo, J. Polym. Sci., Part A: Polym. Chem., 2007, 45, 3408-3414. 